\title{
Shallow Geothermal Energy Resources for Future Utilization in Jordan
}

\author{
Sanaa Al-Zyoud \\ Department of Applied Earth and Environmental Sciences, Institute of Earth and Environmental Sciences, Al al-Bayt University, \\ Al Mafraq, Jordan \\ Email: alzyoud@aabu.edu.jo
}

How to cite this paper: Al-Zyoud, S. (2019) Shallow Geothermal Energy Resources for Future Utilization in Jordan. Open Journal of Geology, 9, 783-794. https://doi.org/10.4236/ojg.2019.911090

Received: August 15, 2019

Accepted: October 9, 2019

Published: October 12, 2019

Copyright (c) 2019 by author(s) and Scientific Research Publishing Inc. This work is licensed under the Creative Commons Attribution International License (CC BY 4.0).

http://creativecommons.org/licenses/by/4.0/

\begin{abstract}
Geothermal energy is considered as one of the new-green-free renewable energy resources that Jordan is blessed with. Geothermal energy installation in Jordan will have a positive impact on the economy, it will reduce the national energy bill. Shallow geothermal systems are likely to be promising for future utilization in the country. Therefore, further evaluations of geothermal energy resources are highly recommended. Distributed efforts have been done to evaluate the potential of geothermal resources utilization in Jordan. A comprehensive geothermal resources assessment has not yet been conducted in the country. The present work evaluates the potential of four geothermal fields in Jordan. Geothermal gradient map shows that Jordan has two high geothermal gradient fields with higher than $4.5^{\circ} \mathrm{C} / 100 \mathrm{~m}$ and other two moderate geothermal gradient fields with a range of $3.5-4.5^{\circ} \mathrm{C} / 100 \mathrm{~m}$. It has been found that the water temperature in some fields reaches about $68.5^{\circ} \mathrm{C}$. Five possible heat source hypotheses were discussed. Geothermal potential in Jordan is expected to evolve as a result of NS trending Dead Sea Rift activities. With the presence of faults parallel with geothermal gradient anomalies in each evaluated field, this hypothesis becomes the most effective to explain the heat source. It is of utmost importance to consider the geothermal energy potential for future utilization in Jordan. An integrated geothermal potential map will be very helpful for energy policies and future strategies planning in the country.
\end{abstract}

\section{Keywords}

Geothermal Field, Geothermal Gradients, Tectonic Activities, Heat Source, Jordan

\section{Introduction}

Energy production and consumption is one of the most critical challenges 
worldwide. Whereas the energy supply increases, many energy issues must be considered. As a key of modernization, the magnitude of energy consumption per capita is becoming very important economic consideration for any country, worldwide. In addition, energy production for consumption is a significant component of development [1]. The biggest challenge facing sustainable economic growth development in Jordan is energy production. Jordan is strongly dependent on conventional fossil fuel. Jordan has very modest conventional fuel resources, therefore, most of its energy requirements are met by the imported crude oil and oil products. The country imports (92\%) of its conventional energy fuel which is nearly one fifth of the national GDP. In addition, energy demands have been increased due to population growth parallel with refugees' influx and modern industrialization. This will lead to increase in the per capita consumption. This is expected to double the per capita consumption by 2020 and triple by $2030[2]$.

On the other hand, environmental concerns of using fossil fuel have been increased. Thus, the attention to provide the country with green and renewable energy resources is highly needed. In this regard, the prospective solutions for energy and environment problems in Jordan are through exploiting new renewable energy resources. Therefore, new renewable energy potential is of high importance toward sustainable development considerations.

The national energy strategy (2007) stated that $10 \%$ (which is $1080 \mathrm{MW}$ ) from Jordan's energy needs should be met by renewable energy in 2020. The strategy also seeks to increase the local energy resources dependence to reach (39\%) by 2025 [2].

An important contribution of future renewable energy supply in Jordan could be provided by geothermal energy. It has been recognized that renewable energy resources are clean, safe and reliable resources. Geothermal energy applications are differing upon the heat source geocharacteristics, reservoir depth and heat. Many applications of geothermal energy can be implemented, for direct and indirect utilization, irrespective of the systems are of shallow or deep enthalpy. Geothermal energy is a reliable power source which could produce electricity with minimum environmental impacts [3].

Early geothermal explorations were conducted by Natural Resources Authority (NRA) which is currently integrated as a part of Ministry of Energy and Mineral Resources (MEMR). Different investigations of geothermal energy evaluation in Jordan have been carried out from early 1965 to present ([4]-[12]). Recently, geothermal energy applications in Jordan have been evaluated for power generation, heating and cooling purposes ([13] [14] [15] [16] [17]).

Despite the studies that early evaluated the geothermal resources in Jordan, no comprehensive revision was applied recently. Scattered efforts for investigating geothermal resources potential in Jordan will not deliver full clear plan for future utilization. The present work comes to find the linkage between new exploited and existing geothermal resources in Jordan. A complete overview for geother- 
mal resources in Jordan will be easily integrated in future energy policies in the country.

\section{Geothermal Energy Resources in Jordan}

Jordan is blessed with different low enthalpy geothermal fields scattered all around the country. The current investigations revealed a considerable geothermal potential in several fields. Geothermal gradient map shows that Jordan has two high geothermal gradient fields of higher than $4.5^{\circ} \mathrm{C} / 100 \mathrm{~m}$ and other two moderate geothermal gradient fields with a range of $3.5-4.5^{\circ} \mathrm{C} / 100 \mathrm{~m}$. Therefore, Jordan can be considered as a rich of low geothermal enthalpy resources country. All mentioned fields with their geothermal gradients are illustrated in Figure 1 bellow.

[9] reviewed [18] and found that the highest gradient two fields are; first (Field 1; Dead Sea Fault Geothermal Field) is the Dead Sea East Escarpment where Lower Cretaceous Sandstone to Upper Cretaceous Limestone represents the geothermal reservoir in this area. In addition, about 50 thermal springs were discharge thermal water in this field ranges in temperature between $33^{\circ} \mathrm{C}$ to $61.5^{\circ} \mathrm{C}$ [11]. This field extends, in about $250 \mathrm{~km}$ length, from Shuneh near the Jordanian Syrian borders to the south at Afra and Burbeitta [23].

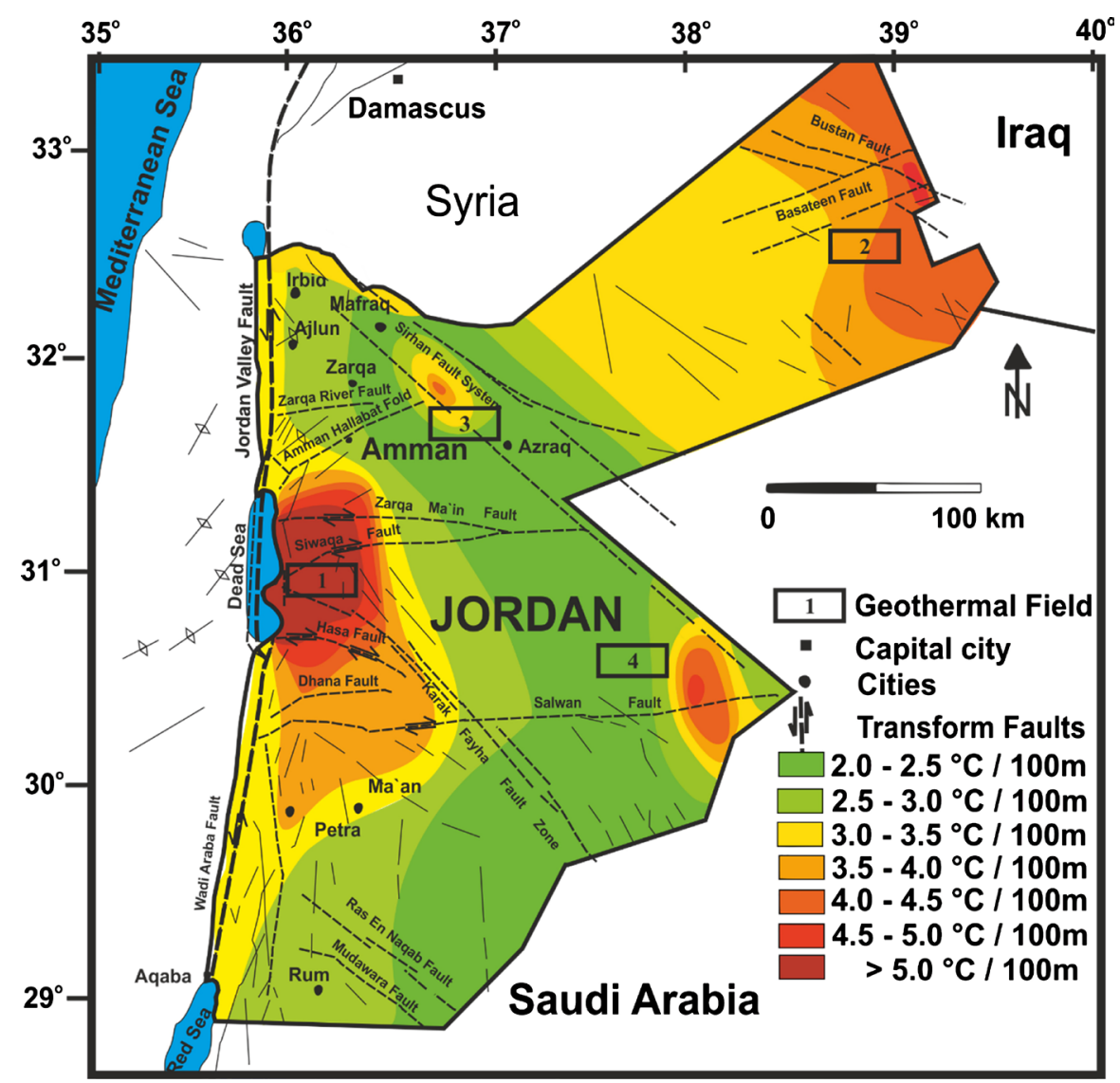

Figure 1. Jordan updated geothermal gradient map indicates four main geothermal fields (after [18] [19] and [20]; Structural map of Jordan (after [21] and [22]). 
[24] and [25] stated that along this field there are more than 150 springs. They reported that more than 100 thermal wells are scattered all over Jordan especially south of Amman, the Azraq, Risha and Sirhan areas. In addition, they reported a summary of some wells in this field (Table 1).

The second field (Field 2; Ar Risha Geothermal Field) of high geothermal gradient locates nearby the tripoint border area (Jordan-Syria-Iraq) in the northern eastern desert. It was discovered during oil and gas exploration in the deep reservoirs there. This area does not receive much geothermal reservoir Table 1. Selected thermal springs and wells in Jordan [24].

\begin{tabular}{|c|c|c|}
\hline Location & Flow rate $\left(\mathrm{m}^{3} / \mathrm{h}\right)$ & Temperature range $\left({ }^{\circ} \mathrm{C}\right)$ \\
\hline \multicolumn{3}{|l|}{ 1. Thermal springs (part of Field 1) } \\
\hline${ }^{\star A l-H i m m a, ~ A l-M u k h a y b a ~}$ & 641 & 36.2 \\
\hline${ }^{\star}$ Hammamat Al-Beda, Wadi Abu Ziad & 1.69 & 48.7 \\
\hline Abu Thableh thermal spring & 17 & 37 \\
\hline Deir Alla thermal spring & 17 & 35 \\
\hline${ }^{\star}$ Mu'ath Bin Jabal, Shuna Shimali & 900 & 57.5 \\
\hline Wadi Hisban thermal spring & - & 32 \\
\hline Ain El Hammam & - & 36 \\
\hline El Dachruk (Zarqa River) & - & 34 \\
\hline Suweimeh & - & 27 \\
\hline Ain Ez Zarqa & - & $20-34$ \\
\hline Zarqa Ma'in ( 60 thermal springs) & - & 63 \\
\hline Burbeita & - & 38 \\
\hline Afra springs & $50-100$ & $44-48$ \\
\hline Zara (45 thermal springs) & - & 53 \\
\hline Zara 1 & 800 & 54 \\
\hline Zara 2 & 67 & 59 \\
\hline Wadi Ibn Hammad springs & - & 35 \\
\hline Weida'a thermal spring & - & 32 \\
\hline North Shauna well & 350 & 57 \\
\hline Kafrain wells & - & $33-36$ \\
\hline \multicolumn{3}{|l|}{ 2. Wells } \\
\hline \multicolumn{3}{|c|}{ Zara and Zarqa Ma'in exploration wells (part of Field 1) } \\
\hline A-GTZ 2D & - & 68.5 \\
\hline B-GTZ 3D & - & 57 \\
\hline TSD1 well—Ghor El Haditha area & 400 & 50 \\
\hline${ }^{* *}$ Queen Alia Airport & $30-100$ & $30-45$ \\
\hline${ }^{* * * A l}$ Khalidiyya Geothermal Field (Field 3) & $250-500$ & $39-46$ \\
\hline
\end{tabular}

${ }^{*}[11],{ }^{* *}[9],{ }^{* * *}$ This work. 
characterization evaluations, yet. In this field, thermal wells discharge warm water from the Upper Cretaceous Limestone aquifer [23].

The other moderate potential regions which exhibit $3.5-4.5^{\circ} \mathrm{C} / 100 \mathrm{~m}$ geothermal gradient are neither evaluated nor exploited yet. They are first time discussed in this work. The first region (Field 3; Al Khalidiyya Geothermal Field) extends from Azraq to the east till Zarqa city (Al Khalidiyya and Ad Dhulail districts) ends north at $\mathrm{Al}$ Mafraq city. It has been found that this area is enriched with thermal water wells where the temperature ranges between $39^{\circ} \mathrm{C}$ to $46^{\circ} \mathrm{C}$ (Table 1). The average geothermal gradient in this area is expected to be about $4^{\circ} \mathrm{C} / 100 \mathrm{~m}$. Wells discharge warm water from both Lower Cretaceous Limestone and Upper Cretaceous Sandstone. The second moderate geothermal potential region (Field 4, SE Desert Geothermal Field) is in lined with Saudi Arabian-Jordanian borders. It has been found that the geothermal gradient reaches $5.0^{\circ} \mathrm{C} / 100 \mathrm{~m}$ in some areas in this region [18]. No recent updates on geothermal gradients as well as geothermal potential in this region were completed.

\section{Geologic Settings}

The oldest rocks in Jordan are found in the southern part of the country. Aqaba and Araba complex of igneous and metamorphic rocks provinces as a part of Nubian-Arabian shield represent these rocks. In the Neoproterozoic between (710 and $630 \mathrm{Ma}$ ) this crystallized rocks were originated from the continental collusion of Gondwana. Un-metamorphosed Cambrians to Silurian sedimentary rocks are overlying the pre-Cambrian rocks in this area. Um Ishrin sandstone and marine siltstone with dolomite were deposited (in Cambrian) above the igneous basement as a result of Jordan being a shelf area. Disi fine-white-sandstone which extends northern ward represents one of the regression activities happened on Ordovician-Silurian time. Different regressions-transgressions followed at this time deposited mudstones and fine sandstone.

When Jordan was a part of Pangaea, most Devonian and Carboniferous rocks were eroded. During the Triassic, western and northern Jordan became a shelf again; therefore, a continental clastics (i.e. sandstone) followed by marine clastics and carbonates (i.e. marl and carbonates) were deposited. These sediments represent a transgression of the Tethys Ocean from the northwest. Many successive transgression and regression were repeated during Mesozoic. Lower Cretaceous thick Kurnub sandstone was deposited at this time. This sandstone represents, with other Middle Mesozoic clastic and marine carbonates with $\mathrm{Pa}$ leozoic deposits, the other middle and lower aquifer system in Jordan. Most deep thermal wells reach this aquifer in different depths. A widely carbonate deposition occurred in the upper cretaceous comprising marl, limestone, and dolomitic limestone. The lower part of this group (Ajlun group) is of marl composition which acts as an aquiclude. While the upper part of Ajlun group with Belqa group of carbonates, as well as Tertiary carbonates, composes the upper aquifer system in north and eastern Jordan. Shallow geothermal wells springs discharge 
from this aquifer.

The geothermal potential in Jordan is expected to become as a result of NS trending Dead Sea Rift activities. This transform fault extends between Zagros-Taurus zone of a convergence boundary to a spreading divergent plate boundary northern Dead Sea. This Cenozoic break up fault happened since Late Miocene with a driven force of Red Sea floor spreading with a rotational north ward movement of the Arabian Plate. The transform fault geometry with associated fractures systems will lead to broaden the groundwater flow path opportunities in Dead Sea Rift system, a natural flow net resulted from enhanced fractured system accompanied with the rift activities. This tectonic activity initiates a large set of regional faults in Jordan with NNE, NNW, SSW and EW directions.

The present continuation of the East African Rift System creates a strike-slip-left lateral movement of a total of $105 \mathrm{~km}$ in Jordan side. The western Jordan border starting from lake Tiberies-Jordan Valley-Dead Sea-Wadi Araba and ending with Red Sea presents the Afro-Arabian plates borders as an extension of East African Rift System. This opening movement generated volcanic activities during Miocene and Pliocene forming Harrat basalt plateau in Jordan. Dead Sea is the main output of this rift in Jordan. It lies about $434 \mathrm{~m}$ below sea level [26] which leads to acting as a slurp for regional groundwater flows over wide area.

The geology of Jordan was early overviewed by [5] [27] and [28]. The structural settings of the area were discussed by [21] and [22]. [13] overviewed the groundwater flows into the Dead Sea system while [29] discussed the geothermal energy resources in Jordan. Being a tectonically active region, Jordan can be considered as a promising source of geothermal energy in the Middle East.

\section{Heat Source}

Geothermal reservoir temperatures were estimated using different geothermometers. Several investigations had been done to explain the heat source in geothermal fields in Jordan. Five possible heat sources were considered for the region as follows:

1) [5] and [7] concluded that water is heated by the cooling during crystallization magma plutonic bodies. The volcanic activities which lead to extrude basalts (Late Cenozoic) are responsible for heating of the adjacent areas. [30] concluded that it seems unlikely that heat source in central Jordan (Dead Sea Fault Geothermal Field (Field (1)) is of magmatic origin. On the contrast, Al Khalidiyya Geothermal Field (Field 3) is located within the Harrat area, therefore, it's probable that heat source in this region is of magmatic origin. However, extended thermochemical investigations as well as isotope geothermometers are needed to verify this conclusion in terms of rock/water genesis and age. In addition, other tectonic activities and structural forms could have a role in heating waters in this region.

2) The second hypothesis was adopted widely by [5] [23] and [31] to explain heat source in some geothermal fields in Jordan. It's concluded that the water is 
heated by deep circulation influenced by the geothermal gradient in the region. Such water directly moves upwards along deep intersecting faults to be discharged as hot springs or to be extracted from some thermal wells. A normal geothermal gradient could play an important role for water temperature rising with deep circulation. The four geothermal fields mentioned in this work exceed the average geothermal gradient in Jordan which is about $3.3^{\circ} \mathrm{C} / 100 \mathrm{~m}$.

As Jordan is tectonically active, most reservoirs have enormous sets of faults with different depths and directions [22]. Fault system in Jordan is reconnecting the two aquifer systems (Upper Limestone and Lower Sandstone systems). In the presence of some geothermal gradient anomalies in each mentioned field (Figure 1), this hypothesis become the most effective one on explaining the heat source for most geothermal fields in Jordan. Field 1; Dead Sea Fault Geothermal Field is a tectonically active area where the main NS Dead Sea Faults intersects.

For instance, it has been found in Al Khalidiyya Geothermal Field (Field 3) that the highest water temperatures are exhibited by wells drilled along the dominant fault direction in the area (i.e. NW to SE). The intersection of EW Zarqa fault with the NW Sirhan fault gives an obvious evidence of such hypothesis on heat source in this field. It's possible that the heat source of the fourth geothermal field at Al Jafr basin is an output of faults intersection zone where EW Salwan fault intersecting the southern extension of Sirhan fault. For a certain fault depth, deep water circulation could be the dominant hypothesis for heat source in this area. It can be outlined that Ar Risha Geothermal Field (Field 2), where NW-SE Bustan fault intersects NEE-SWW Basateen faults, has the same heat source structural conditions. Nevertheless, gas emissions, isotope and chemical geothermometer should be implemented in the investigated fields in order to demonstrate their heat source hypothesis. [32] has found that radon gas is of high concentrations in such fault's intersections. However, faults depth and extension should be considered while investigating heat sources in the geothermal fields under this hypothesis. It's expected that other regions in Jordan with a similar tectonic setting may exhibit future geothermal potential, too. Other prospective field could be located at the intersection of a) Zarqa-Main with Sewaqa faults southern Al Mwaggar village, b) Karak Fayha with Salwan faults north eastern Ma'an city, c) Wadi Araba with Mudawara and Ras En Naqab faults northern Rum village. Nevertheless, an extensive thermo-structural investigation needs to be implemented in these regions.

3) The lateral movement of Dead Sea Rift fault is associated with friction, such shearing area is likely to be responsible for heating the surrounded water along the fault zone. It has been found that the hottest springs are highly connected with the existence of shearing areas [33]. [33] concluded that the heat source in Zarqa-Mai'n area (Dead Sea Fault Geothermal Field (Field (1)) is associated with the Zarqa-Ma'in fault zone rather than the local basaltic eruptions.

Another less common hypothesis had been discussed for heat source explanation in Jordan: 
4) Radioactive heat production due to U238 disintegration series in Lower Sandstone aquifer [31] with [23]. Several geological settings are affecting this hypothesis; rock types and genesis, tectonic activities, mineral composition... and other controllers would limit this hypothesis acceptance. Further investigations are highly recommended for the adoption of this hypothesis.

5) Heat stowing horizon of sandstone overlain by marls will double the geothermal gradient as the sand is dry and have half of wet sandstone thermal conductivity [34].

[23] concluded that the highest temperature predicted by using mineral saturation index for the lower geothermal reservoir in Jordan is $115^{\circ} \mathrm{C}$. In addition, a stable isotope analysis showed that the thermal water is of meteoric origin. They approved that the deep circulation of water with cold (shallow) and warm (deep) water mixing is the most obvious explanation of heat source. [35] studied the reason of temperature raise in the lower aquifer system in Jordan. They estimated the Zarqa-Main heat flow to be $472 \mathrm{~mW} / \mathrm{m}$.

\section{Suggested Applications}

In Jordan, geothermal energy has different utilization. Now, it is used for direct and indirect applications. Thermal water is currently utilized as curative water for its therapeutic value. Dead Sea Fault Geothermal Field (Field (1)) represents the largest thermal spa area in Jordan. Water mineralization and high temperature in this area lead to be exploited for treating lots of human disorders. Another direct usage which is adopted in Al Khalidiyya Geothermal Field (Field (3)) is for agricultural purposes. As this water is enriched with the needed nutrients, water mineralization provides unique cations/anions needed by some crops. Some fish farming is implemented in geothermal fields ( 1 and 3 ) as well. The other fields ( 2 and 4 ) haven't been considered for direct geothermal utilization yet.

On the other hand, indirect geothermal energy has been applied in space heating and cooling for some public infrastructure (i.e. The American University of Madaba, The National Center for Research and Development building at the Higher Council of Science and Technology). Ground source heat pumps and exchange applications become a promising environmental geothermal application ([16] [17] [31] [36] [37]).

International Geothermal Association (IGA) stated that Jordan installed capacity for geothermal energy is $153.3 \mathrm{MWh}$ while the prospective geothermal potential is $1540 \mathrm{TJ} / \mathrm{yr}$. Therefore, the overall capacity factor does not exceed 0.42 for the geothermal energy utilization in Jordan currently ([10] [38]).

Geothermal energy in Jordan has not been utilized for electric power, fish farming, green house heating, food industry and groundwater desalinization yet. Further investigations must be implemented to evaluate the feasibility of such applications.

Geothermal energy systems installation in Jordan will have a positive impact 
on the economy, it will reduce the national energy bill. For instance, in order to satisfy techno-economic feasibility for power generation in Dead Sea Fault Geothermal Field (Field (1)) the depth of $3.000 \mathrm{~m}$ is highly considered for drilling in this area [2]. Nevertheless, it has been found that the usage of geothermal heat exchangers for infrastructure heating and cooling in central Jordan will lead about $15 \%$ - $30 \%$ savings in energy consumption [37]. In northern Jordan, ground heat pump is calculated to save $60 \%$ of electric consumption for heating purposes. While it will save $50 \%$ of electric consumption for cooling purposes compared to the available conventional energy resource in this area [17]. This savings in electric consumption will lead to save in fuel oil consumption. Therefore, an obvious reduction of $\mathrm{CO}_{2}$ emissions could be noticed while switching to geothermal energy.

In general, direct environmental impacts of geothermal utilizations are negligible and controllable. However, on the long run, the local environmental impacts should be considered.

\section{Conclusions}

Geothermal energy, as a new renewable energy potential, is of high importance toward sustainable development considerations in Jordan. Jordan is blessed with different low enthalpy geothermal fields scattered all around the country. Geothermal gradient map shows that Jordan has four promising geothermal fields with a considerable potential for future utilization: 1) Dead Sea Fault Geothermal Field, 2) Ar Risha Geothermal Field, 3) Al Khalidiyya Geothermal Field and 4) SE Desert Geothermal Field. The geothermal potential in Jordan is expected to evolve as a result of NS trending Dead Sea Rift activities. Five possible heat sources were discussed, the most adopted hypothesis is concluded that water is heated by deep circulation along existing intersecting faults influenced by the geothermal gradient in the region. A normal geothermal gradient could play an important role in water temperature rising with deep circulation. The four geothermal fields mentioned in this work exceed the average geothermal gradient in Jordan which is about $3.3^{\circ} \mathrm{C} / 100 \mathrm{~m}$.

It's expected that other regions in Jordan which have a similar tectonic setting may exhibit future geothermal potential, too. Other prospective fields could be located at the intersection of main faults in Jordan. Nevertheless, an extensive thermo-structural investigation needs to be implemented in these regions. Geothermal energy in Jordan had not been utilized for electric power, fish farming, green house heating, food industry and groundwater desalinization yet. Further investigations must be conducted to evaluate the feasibility of such applications. The complete overview for geothermal resources in Jordan which had been given in this work will be integrated for future energy policies in the country.

\section{Conflicts of Interest}

The author declares no conflicts of interest regarding the publication of this paper. 


\section{References}

[1] Reddy, A., Williams, R. and Johansson, T. (1997) Energy after Rio: Prospects and Challenges. UNDP, New York.

[2] Abdul Rahim, N. (2014) Renewable Energy Prospects in Jordan, Economic \& Commercial Counsellor Jordan, Invest-Export. Brussels Report, 12 p.

[3] Kömürcü, M.I. and Akpinar, A. (2009) Importance of Geothermal Energy and Its Environmental Effects in Turkey. Renewable Energy, 34, 1611-1615. https://doi.org/10.1016/j.renene.2008.11.012

[4] MacDonald, M., et al. (1965) East Bank Jordan Water Resources. Report to Central Water Authority, Hashemite Kingdom of Jordan.

[5] Bender, F. (1974) Geology of Jordan. Contribution of the Regional Geology of the Earth. Gebruder Borntraeger, Berlin.

[6] Truesdell, A. (1979) Final Report on the Chemistry and Geothermal Energy Possibilities of the Zara-Zarqa Ma'in Springs, Jordan. U.S. Geol. Survey, Ment Park.

[7] Abu-Ajamieh, M. (1980) The Geothermal Resources of Zarqa Ma'in and Zara. NRA, Amman.

[8] Swarieh, A. (1992) Thermal Boreholes near Queen Alia Airport. NRA, Amman, 47 p.

[9] Swarieh, A. (2000) Geothermal Energy Resources in Jordan, Country Update Report. Proceedings of the World Geothermal Congress, Kyushu-Tohoku, 28 May-10 June 2000, 469-474.

[10] Hrayshat, E.S. (2009) Status and Outlook of Geothermal Energy in Jordan. Energy for Sustainable Development, 13, 124-128. https://doi.org/10.1016/j.esd.2009.05.004

[11] Schäffer, R. and Sass, I. (2014) The Thermal Springs of Jordan. Environmental Earth Sciences, 72, 171-187. https://doi.org/10.1007/s12665-013-2944-4

[12] Al-Hinti, Al-Muhtady, A. and Al-Kouz, W. (2017) Measurement and Modelling of the Ground Temperature Profile in Zarqa, Jordan for Geothermal Heat Pump Applications. Applied Thermal Engineering, 123, 131-137. https://doi.org/10.1016/j.applthermaleng.2017.05.107

[13] Abu-Hamatteh, Z., Al-Zughoul, K. and Al-Jufout, S. (2011) Potential Geothermal Energy Utilization in Jordan: Possible Electrical Power Generation. International Journal of Thermal and Environmental Engineering, 3, 9-14. https://doi.org/10.5383/ijtee.03.01.002

[14] Al-Zyoud, S. (2012) Geothermal Cooling in Arid Regions: An Investigation of the Jordanian Harrat Aquifer System. Doctoral Dissertation, Technische Universität Darmstadt, Darmstadt, $122 \mathrm{p}$.

[15] Al-Zyoud, S., Rühaak, W. and Sass, I. (2014) Dynamic Numerical Modeling of the Usage of Groundwater for Cooling in North East Jordan-A Geothermal Case Study. Renewable Energy, 62, 63-72. https://doi.org/10.1016/j.renene.2013.06.027

[16] Al-Khasawneh, Y., Albatayneh, A. and Althawabiah, S. (2019) The Application of Ground-Source Heat Pumps for a Residential Building in Jordan. In: Alalouch, C., Abdalla, H., Bozonnet, E., Elvin, G. and Carracedo, O., Eds., Advanced Studies in Energy Efficiency and Built Environment for Developing Countries, Springer, Berlin, 161-167. https://doi.org/10.1007/978-3-030-10856-4_16

[17] Al Dhoun, H. and Al-Zyoud, S. (2019) Geochemical Assessments and Potential Energy Sources Evaluations Based on Oil Shale and Geothermal Resource in Wadi Al-Shallala-North Jordan. International Journal of Geosciences, 10, 351-365. 
https://doi.org/10.4236/ijg.2019.103020

[18] Myslil, V. (1988) Report on Evaluation of Geothermal Potential of Jordan. Strojexport Prague, Gzechoslovakia, Geological Survey, Prague.

[19] Williams, H., Ramini, H. and Alzyoud, M. (1990) Regional Petroleum Geochemistry of Jordan. Natural Rescources Authority, Amman, 66 p.

[20] Gharaibeh, A. (2008) Heat Source Study and Geothermal Reservoir Assessment for the Zarqa Ma'in-Dab'a Area, Central Jordan. United Nations University, Geothermal Training Program, Reykjavik, 221-246, Report 17.

[21] Kashai, E.L. and Croker, P.F. (1987) Structural Geometry and Evolution of the Dead Sea-Jordan Rift System as Deduced from New Subsurface Data. Tectonophysics, 141, 33-60. https://doi.org/10.1016/0040-1951(87)90173-9

[22] Diabat, A. (2004) Structural Map of Jordan. Unpublished Report, Natural Resources Authority, Amman.

[23] Saudi, A. and Swarieh, A. (2015) Geothermal Energy Resources in Jordan, Country Update Paper. Proceeding of World Geothermal Congress, Melbourne, 19-25 April 2015, 5 p.

[24] Sunna, B. (2004) Recommended Approaches to Develop the Direct Utilization of the Geothermal Energy (Hot Water) in Jordan. Jordan Aqua Conservation Association (JACA), International Water Demand Management Conference, Jordan.

[25] Sunna, B. (2015) Occurrences and Possible Applications of Geothermal Energy in Jordan. International Conference on Geology, Florida, 22-23 June 2015.

[26] Alrai Newspaper (2019) Dead Sea May Disappear Soon, in Arabic. http://alrai.com/article/10497563

[27] Quennell, A.M. (1958) The Structure and Geomorphic Evolution of the Dead Sea Rift. The Quarterly Journal of the Geological Society of London, 64, 1-24. https://doi.org/10.1144/gsigs.114.1.0001

[28] Burdon, D.J. (1959) Handbook of the Geology of Jordan: To Accompany and Explain 1:250,000 Geological Map of Jordan East of the Rift by A. M. Quennell. Government of the Hashemite Kingdom, Amman.

[29] Swarieh, A. (2008) Geothermal Water in Jordan. United Nation University Geothermal Training Programme, Tianjin.

[30] Swarieh, A. (2005) Heat Sources of the Groundwater in the Zara-Zarqa Ma'in-Jiza Area, Central Jordan. University of Karlsruhe, Karlsruhe.

[31] Al-Dabbas, M. (2011) Achievement of Geothermal Energy Using Ground Heat Exchanger in Ma'in. Journal of Mechanical Science and Technology, 25, 2013-2023. https://doi.org/10.1007/s12206-011-0520-y

[32] Saudi, A., Swarieh, A., Diabat, A., Masri, A. and Masarwih, R. (2004) Thermal Fluids in Central Jordan. NRA, Amman, $125 \mathrm{p}$.

[33] Hakki, W. and Teimeh, M. (1981) The Geology of Zarqa Ma'in and Zara Areas. NRA, Amman.

[34] Salameh, E. (1986) The Reason of Elevated Temperature in the Lower Aquifer Complex in Central Jordan. Ground Water in Semiarid and Arid Regions. Proceedings of the International Congress, Amman, 240-255.

[35] Galanis, S.P., Sass, J.H., Munroe, R.J. and Ajamieh, A. (1986) Heat Flow at Zarqa Ma'in and Zara and a Geothermal Reconnaissance of Jordan. U.S. Geol. Survey. https://doi.org/10.3133/ofr86631

[36] Al-Sarkhi, A., Akash, B., Abu-Nada, E., Nijmeh, S. and Al-Hinti, I. (2008) Prospects 
of Geothermal Energy Utilization in Jordan. Energy Sources, Part A: Recovery, Utilization, and Environmental Effects, 30, 1619-1627. https://doi.org/10.1080/15567030701436388

[37] Abu Raed, A.S. and Sakhrieh, A.H. (2013) Energy Saving by the Means of Geothermal Energy. Journal of Clean Energy Technologies, 1, 243-245.

[38] International Geothermal Association (IGA) (2018) Geothermal Power Database. https://www.geothermal-energy.org/explore/our-databases/geothermal-power-data base 